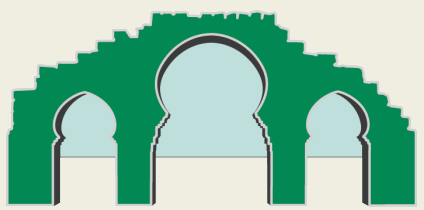

argelina.org
Revista Argelina

Revista semestral de Estudios Argelinos

Primavera 2015

Número Cero

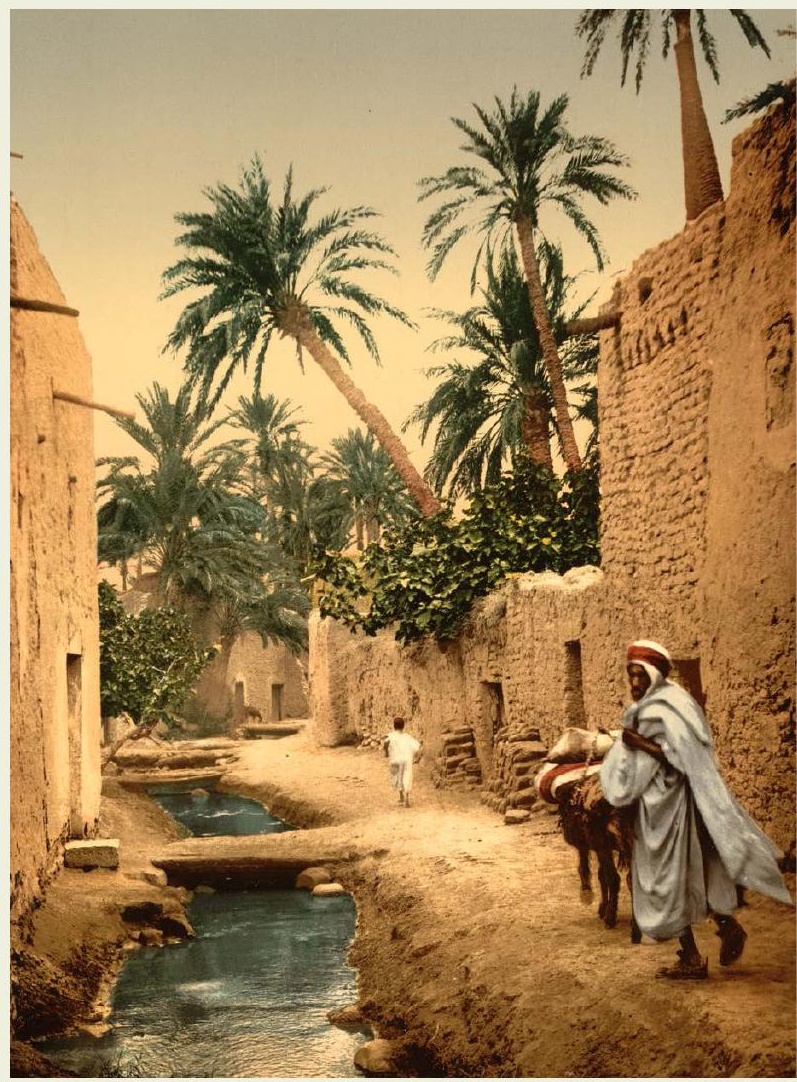


Número 0 • Primavera 2015

\section{Revista Argelina}

Revista semestral de Estudios Argelinos 


\section{Revista Argelina}

Revista semestral de Estudios Argelinos

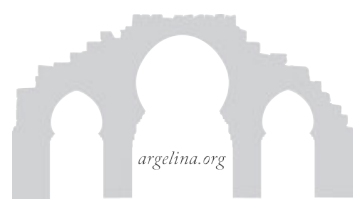

Revista Argelina. Revista semestral de Estudios Argelinos es una publicación electrónica semestral editada por el Área de Estudios Árabes e Islámicos de la Universidad de Alicante que edita dos tomos anuales de investigación y reflexión en torno a las letras, cultura, historia y actualidad de Argelia. Una versión extendida de la revista se publica en papel por la Editorial Hispano-Árabe.

\section{Comité editorial:}

Directora: Naima Benaicha Ziani

Subdirector: Isaac Donoso

Secretario técnico: Didac Conesa

Exención de responsabilidad:

Las opiniones y datos contenidos en cada texto son de exclusiva responsabilidad de sus autores. Revista Argelina no comparte necesariamente las opiniones vertidas por los autores ni se hace responsable de los trabajos.

$$
\begin{gathered}
\text { Imprime: } \\
\text { Editorial Hispano-Árabe } \\
\text { http://www.editorial-hispanoarabe.com } \\
\hline \text { Calle de los Jazmines No } 17 \\
\text { Talamanca de Jarama } \\
28160 \text { Madrid } \\
\text { Tel. } 639707720 \\
\text { Correspondencia y redacción: }
\end{gathered}
$$

Área de Estudios Árabes e Islámicos de la Universidad de Alicante, Carretera de San Vicente del Raspeig, s/n, 03690 Alicante.

La revista esta disponible a texto completo en internet en la dirección siguiente: $\underline{\text { http://argelina.org }}$

Portada:

Calle en Biskra, Argelia, en «Imágenes de pobladores y sitios de Argelia» del catálogo de la Detroit Publishing Company (1905)

(C) De los autores de los artículos originales.

(C) Revista Argelina, 2015 


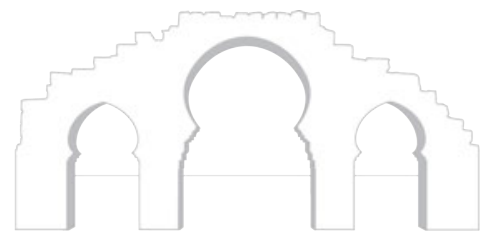

Revista Argelina • Número 0 • Primavera 2015

\section{ÍNDICE}

\section{Presentación}

La Universidad de Alicante y los «Estudios Argelinos»: una publicación necesaria

Artículos y notas

IsAaC DONOSO

Al-Hādì al-Sanūsì y la concepción de la cultura argelina

NAIMA BENAICHA ZIANI

Sobre el lenguaje en el teatro árabe argelino (I)

Reseñas y comentarios bibliográficos

IsAAC Donoso

Antologias de poesía argelina contemporánea en lengua árabe

Biblioteca

NAIMA BENAICHA ZiANI

L'enfant-jazz de Mohammed Dib 



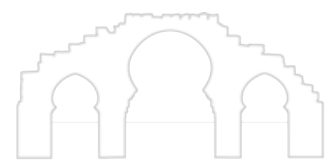

Presentación 



\section{PRESENTACIÓN}

\section{LA UNIVERSIDAD DE AlicANTE Y LOS «EstUdios ARGELINOS»: UNA PUBLICACIÓN NECESARIA}

Argelia ha sido históricamente lugar de refugio y exilio para heterodoxos españoles, moriscos expulsados, berberiscos renegados, mancos de Lepanto, agricultores depauperados, y toda una serie de población, sobre todo alicantina, que ha encontrado en la otra orilla lo que en ésta no tenía. A lo largo de la historia, Argelia ha ido construyendo una cultura meridional mediterránea y sahariana de la que Alicante ha sido parte muy importante, $y$ donde el trasvase poblacional ha sido tradicionalmente de norte a sur.

Tras un final de siglo XX traumático para la historia de Argelia, el siglo XXI se presenta esperanzador para un país que, en un contexto de inestabilidad regional generalizado, desea por fin construir su prosperidad. $Y$ en este contexto se debe de acometer el estudio de Argelia en términos modernos, abandonando los planos soslayados o interesados, pues la constitución cultural y nacional argelinas forman a día de hoy una de las principales esferas y referentes de la modernidad árabe.

Los «Estudios Argelinos» representan un campo de estudios con notable tradición entendidos en su clave francófona, pero con escasa atención intrínseca tanto arabo-islámica como beréber. Y dentro de estos estudios, igualmente ha sido escasa la atención que la universidad española ha prestado a la cultura de uno de nuestros vecinos directos. Es por todo ello que el Área de Estudios Árabes e Islámicos de la Universidad de Alicante, 
desde su creación y atendiendo a sus mandatos fundacionales, ha tenido especial predilección por los Estudios Argelinos y la vinculación natural con el mundo académico de la orilla meridional. Desde Marcelino Villegas y Míkel de Epalza, principales referencias españolas en el conocimiento de la cultura argelina, con largas estancias en universidades de Argelia, hasta F. Franco-Sánchez, Luis Bernabé y Eva Lapiedra, y el establecimiento de convenios privilegiados entre instituciones de ambas orillas, la Universidad de Alicante ha seguido y sigue la realidad cultural de una sociedad que le es necesaria por naturaleza.

Es por todo ello que la creación de una publicación especializada exclusivamente en el fomento de los Estudios Argelinos parezca necesaria y natural a la historia y cometidos de la Universidad de Alicante. Con tal objeto se presenta «Revista Argelina», publicación semestral compuesta por ensayos, artículos y notas, reseñas y comentarios bibliográficos, y sección de biblioteca, buscando cumplir un mandato ineludible y cubrir un espacio necesario para la agitación, dinamización, reflexión y estudio de la cultura histórica y presente del pueblo argelino.

ISAAC DONOSO 


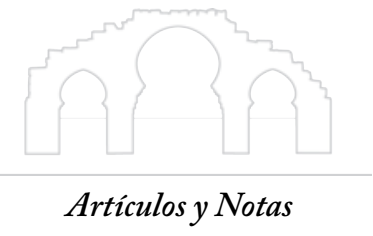





\title{
AL-HĀDĪ AL-SANŪSİ Y LA CONCEPCIÓN DE LA CULTURA ARGELINA
}

\author{
IsAaC DONOSO
}

Universidad de Alicante

Muhammad al-Hādī bin 'Alī bin Muḥammad bin al-Sanūsī alZāhirī / محمد الهادي بن علي بن محمد بن السنوسي الزاهري nació en 1902 en la pequeña aldea de Liana, a unos cincuenta kilómetros de Biskra, capital de la provincia. Se trata de una región prácticamente desértica, donde recibió una educación tradicional en lectura coránica y ciencias de la religión por parte de su entorno familiar. Su destino cambiará cuando se ponga a las órdenes del prestigioso imán 'Abd al-Hamīd bin Bādīs, que acabará siendo una de las figuras fundamentales en la historia moderna de Argelia. En Constantina, y escuchando las lecciones de Ibn Bādīs, al-Hādī al-Sanūsĩ fortaleció su formación islámica no sólo en la ortodoxia de la fe, sino también en la necesidad de una regeneración que permitiera a los argelinos enfrentarse al discurso dominante del colonizador. Frente al poder establecido de una intervención extranjera extremadamente agresiva en términos culturales y educativos, el conocimiento podía permitir a la juventud argelina un camino alternativo a la aculturación y la disociación de las raíces árabo-islámicas de Argelia.

A comienzos de los años 30 del siglo XX, se establece en Biskra para liderar las reivindicaciones de reforma y libertad del pueblo argelino frente a la administración francesa, por medio de la prensa y la propaganda. Igualmente será uno de los fundadores de la Ŷam 'iyya al-'ulamä’ al-muslimin al-ŷazāiriyyin / "جمعية العلماء المسلمين الجزائريين "Asociación de ulemas musulmanes 
argelinos", organismo que hacía hincapié en la identidad islámica de Argelia como herramienta de oposición al colonizador.

Junto a la propaganda, el otro instrumento de oposición al régimen era el fomento de la educación, la formación de una juventud comprometida en valores autóctonos y capacidad de asumir la responsabilidad histórica que le había correspondido. Así que deambuló por diferentes pueblos y ciudades como maestro de escuela. Estas actuaciones de compromiso social despertaron la animadversión de la policía colonial francesa, sufriendo una persecución que le obligó a dedicarse al comercio primero, y a la radio después.

Será el momento en que explote la revolución del primero de noviembre de 1954 que llevará a la consecución final de la independencia de Argelia en 1962. Al-Hādī al-Sanūsī fallece en 1974, habiendo actuado en su vida con la versatilidad que la historia exigía en la situación que le tocó vivir: poeta, maestro de escuela, periodista, activista y militante de la regeneración cultural argelina ${ }^{1}$.

\section{II}

Al-Hādī al-Sanūsī es sobre todo recordado en la actualidad por una obra pionera en la bibliografía argelina, una obra creada a conciencia para establecer las bases de una renovación cultural en lengua árabe. Así, frente a los impulsos de la administración francesa por educar exclusivamente en lengua francesa, instruir y construir una élite cultural afrancesada, con los escasos medios existentes al-Hādī al-Sanūsī realiza una operación paralela, ya no desde la macroestructura de la ingeniería cultural france-

${ }^{1}$ Achour Cheurfi, Écrivains algériens: dictionnaire biographique, Argel, Casbah éditions, 2004, p. 332. Cf. 'Abd al-Hamīd Gannām, Muhammad alHādì al-Sanūsì al-Zābirì. Hayyātu-hu wa šìru-bu, Argel, Manšūrāt al-Šà'ihịi, 1986. 
sa, sino desde abajo, desde la cultura del pueblo, desde los entramados por donde la poesía se había manifestado secularmente ${ }^{2}$. En efecto, la administración francesa estaba tratando de crear una cultura ficticia, una literatura en francés ajena a la tierra y las gentes, una literatura en la lengua del colonizador que a comienzos del siglo XX era una operación generalizada en todo el planeta, desde la literatura filipina en inglés, a la literatura indonesia en holandés, o la literatura vietnamita en francés.

El fuerte desarrollo industrial e imperial de las principales naciones occidentales traducía el concepto de "progreso" en dos claves: la política democrática o republicana y el utilitarismo darwinista, la ley del más fuerte. Su traducción en términos culturales fue la superioridad de la cultura de Occidente frente a la "venalidad y la barbarie oriental". Este "marco civilizado" requería de un cuerpo político educado, adoctrinado, una élite formada según la civilización occidental, que se constituía inmediatamente en clientelista, es decir, políticos y tecnócratas deudores de Occidente. Así como los nihilistas rusos y los cínicos griegos pretendían huir de lo establecido, rechazar la civilización como alienante, y comenzar desde una tabula rasa, el concepto de "civilización" practicado por Occidente afirmaba el estado de barbarie, para desde ese estadio levantar la civilización al gusto del civilizador.

Desde aquí habría que situar el origen, primero, de un Orientalismo al servicio del poder politizador de Occidente y, después, de un postcolonialismo al servicio de la deconstrucción occidental de la cultura oriental, de modo que todo rasgo cultural autóctono ha de ser analizado por el filtro, por la perspectiva, por el trauma que el proceso civilizador ha causado a la cultura autóctona. De ahí el gran cinismo de la llamada "crítica literaria postcolonial", que se contenta con citar a Edward Said

${ }^{2}$ Véase Jean Déjeux, La poésie algérienne. De 1830 à nos jours, París, Publisud, 1996, p. 45. 
para seguir haciendo lo mismo. De este modo es fácil entender que cultura se opone a civilización, intuición a utilitarismo, estética a política, devenir a decadencia, porque, así entendido, la cultura sería un proceso activo de construcción, y la civilización un estado pasivo de organización, que sólo tiene una dirección: la decadencia. Desde esta consigna hay que colegir la inicial escisión entre ciencias del espíritu y ciencias de la naturaleza (y el desarrollo de las ciencias sociales desde un modo de pensamiento francés y las ciencias humanas desde el concepto de la ilustración alemana) $)^{3}$. En este contexto es fácil igualmente imaginar que para la cultura argelina, la agresión "civilizadora" francesa fue traumática para la identidad del pueblo, y la única alternativa de supervivencia era seguir creyendo en la capacidad constructora de la cultura, frente a la civilización impuesta ${ }^{4}$.

\section{III}

Al-Hādī al-Sanūsī es quien comienza a impulsar ese proceso activo de renovación cultural, frente a la inexorable decadencia que un modelo civilizacional representa, cuando se pretende imponer civilización a cultura. $\mathrm{Y}$ esa renovación la ejerce en los dos planos esenciales del ejercicio cultural: la educación y la escritura.

En cuanto a la primera, ya hemos mencionado su formación junto a Ibn Bādīs en Constantina alrededor de los años 20 del

3 "La auténtica idealidad, la idealidad del concepto teórico lo mismo que la de la forma intuitiva, implica siempre un comportamiento productivo, creador, no una actitud puramente receptiva o imitativa. Tiene que crear algo nuevo, en vez de limitarse a repetir lo ya existente, aunque sea bajo otras formas. El arte que no cumpla esta suprema misión a él encomendada, no pasa de ser un entretenimiento ocioso del espíritu, un juego vacuo", en Ernst Cassirer, Las ciencias de la cultura, México, FCE, p. 52.

${ }^{4}$ Cf. Nicolás Sánchez Durá (ed.), Cultura contra civilización: en torno a Wittgenstein, Valencia, Editorial Pre-Textos, 2008. 
siglo pasado, y su papel en la fundación de la Asociación de ulemas musulmanes argelinos. Las enseñanzas de Ibn Bādīs iban dirigidas a renovar el mensaje religioso, entendiendo que las prácticas populares y la religiosidad tradicional se habían alejado del verdadero mensaje coránico. De ahí que una de las principales acciones de la Asociación de ulemas sea la censura de la santería, del culto a los morabitos y místicos, y el seguimiento de las consignas de los renovadores de la Nahda: Ŷamāl al-Dīn (Asadābādī) al-Afgān̄̄ جمال الدين الأفغاني/ (1838-1897) , y Muhammad 'Abduh (1849-1905) / محمد عبده, sobre todo desde el periódico fundado por ambos en París, al-'Urwa al-Watgà / العروة ("E1 nudo indisoluble”).

Hay varios hechos determinantes en la formación de esta doctrina reformista, iṣlāhista (الإصلاح): la visita de Muḥammad Abduh a Argelia en 1903; la celebración de la conferencia de Orientalistas en 1905; y el papel que la mezquita Zaytuna de Túnez tuvo como modelo de enseñanza. En efecto, muchos de los jóvenes argelinos acudían a Túnez, que para entonces era tanto como ir a China, en lo geográfico ${ }^{5}$, como en lo espiritual, siguiendo el precepto del hadit. "Buscad el saber incluso en China, pues la búsqueda del saber es una obligación de todo musulmán" ". La idea de Ibn Bādīs era poder hacer en Argelia un centro tan prestigioso y relevante para el saber islámico como la mezquita Zaytuna tunecina. Sin embargo, la labor de sus discípulos se dispersó por toda la geografía argelina, más allá de Constantina

${ }^{5}$ Como dice el jeque Ṭāhir bin 'Abd al-Salām. Véase 'Abd Allāh Ḥammādī, "Bidāyāt nahụa al-šír al-ŷazāinrī", en Maŷalla Kālīkūt, Universidad de Calicut, vol. 2, núm. 1, 2010, p. 42.

6 Traducción española nuestra. Texto original: اطلبوا العلم ولو بالصين فِإن طلب) (العلم فريضة على كل مسلم . Edición árabe: Ibn 'Abd al-Barr, Ŷāmi' bayān al-'ilm wa-faḍli-hi, Dammam, Dār Ibn al-Ŷawzī, 1994. 
y, más allá de una exclusividad religiosa, el reformismo argelino era también cultural y, sobre todo, nacional: "L'islam est notre religion, l'arabe est notre langue et l'Algérie est notre pays". Frente a ideologías que después van a ir tomando cuerpo, en torno a la idea de nación, patria, estado, panarabismo o panislamismo, Argelia asume desde el primer momento una concepción nacionalista sorprendentemente original dentro del mundo árabe colonizado, donde al hecho de una identidad política, se suma la religiosa (islámica) y cultural (árabe). Al-Hādī al-Sanūsī transmitirá estas enseñanzas en las diferentes madrasas libres en las que estuvo, Argel, Tlemecén y Bel Abbés ${ }^{7}$.

En cuanto a la escritura, al-Hādī al-Sanūsī confecciona una

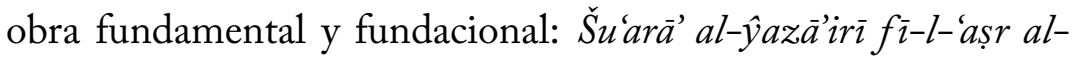
hāạir / شعراء الجزائر في العصر الحاضر "Poetas de Argelia en época contemporánea", publicada en dos volúmene en Túnez entre 1926 y $1927 .{ }^{8}$ Se trata de la primera obra antológica de la poesía argelina en lengua árabe, y una de las primeras obras de su naturaleza en el Mágreb. Fue realizada con un curioso método: cada autor le mandaba su foto, su carta de introducción, su semblanza y su selección de poemas, y todos estos materiales se iban organizando en el libro. El método no podía se otro. Como hemos señalado, frente a la logística cultural francesa, el pueblo argelino tenía escasa capacidad de agitación y dinamización cultural. Lo que había que hacer era reconducir el cauce natural por el que la poesía había transitado secularmente. Y eso hizo al-Hādī al-Sanūsī, contactar a los diferentes autores, reconocidos en sus localidades, para que le mandasen los materiales con los que crear un nuevo objeto: la poesía moderna argelina en

${ }^{7}$ Ahmed Lanasri, Anthologie de la poésie algérienne de langue arabe. Textes arabe et français, París, Publisud, 1994, p. 63.

${ }^{8}$ Edición moderna de 'Abd Allāh Ḥammādī, Constantina, Dār Bahā’ alDīn li-1-Našr wa-1-Tawzī' , 2007, 2 vols. 
lengua árabe, frente a la que se estaba fabricando en francés ${ }^{9}$. Si no se querían abortar las aspiraciones nacionalistas, era necesario construir la modernidad argelina más allá del francés. Consecuentemente, tomando como modelo el neoclasicismo poético egipcio, los poetas argelinos compondrán casidas con temática explícita o implícitamente nacionalista, en torno a la creación de un ideario y una simbología de una Argelia que construía su modernidad ${ }^{10}$.

Entre los autores antologados se pueden destacar Muhammad al-'̄̄d Ham 'Alī, al-Laqānī bin al-Sā’iḥ, Muhammad alSa īd al-Zāhirī, al-Ŷānidī Aḥmad Makkī, Abū al-Yaqzān, alTTayyib al-'Uqbī, Mufdī Zakariyā’ bin Sulaymān, Aḥmad Kātib bin al-Gazālī, Hamūd Ramaụān bin Sulaymān, Ibrāhīm bin Nūh Amtiāz, y el propio al-Hādī al-Sanūsī para el primer volumen. Destaca sin duda la inclusión de Ḥamūd Ramaḍān (19061929) / (حمود رمضان), alumno de la famosa Zaytuna, y poeta que se aleja de los preceptos neoclásicos. En efecto, Hamūd Ramadāan entiende la poesía como un ejercicio de sensibilidad intimista, con una estética que se aleja del neoclasicismo imperante, y está más cercana a sus coetáneos del Dìwān en Egipto (1913-1921) y el Mahŷar en América (1920-31). Consiguientemente, en el conjunto de casidas que forman la antología de alHādī al-Sanūsī, destacan sin duda las formas poéticas experimentadas por este joven poeta, como la transformación de la monorrima hacia la repetición de tres rimas sucesivamente, y

${ }^{9}$ Cf. Ahmed Lanasri, La littérature algérienne de l'entre-deux-guerres: Genèse et fonctionnement, París, Publisud, 1995.

${ }^{10}$ En este sentido, aunque el mundo se asombraba en 1927 de que Charles Lindbergh (لندنبرج) había logrado cruzar en avión el océano Atlántico, para la modernidad del pueblo argelino seguía siendo importante escribir casidas. Véase 'Abd Allāh Ḥammādī, loc. cit., pp. 41-42. 
otras alteraciones que preludían la desestructuración de la poética clásica ${ }^{11}$.

Todo ello nos muestra que al-Hādī al-Sanūsī no era un recalcitrante defensor del neoclasicismo poético, ni del tradicionalismo religioso, ni de la beligerancia armada, sino un verdadero revolucionario de la palabra y la educación, que supo conceptualizar en los dificiles años en los que le tocó vivir la definición de una Argelia moderna fundada en la educación y la cultura.

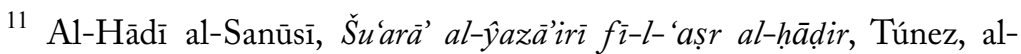
Maṭba'a al-Tūnisiyya, 1926, vol. 1, pp. 169-176. Cf. Șālạ̣ Jarfi, Al-Šír alŷazāirì al-hadìt (La poesía argelina contemporánea), Argel, ENAL, 1984. 


\section{APÉNDICE ICONOGRÁFICO:}

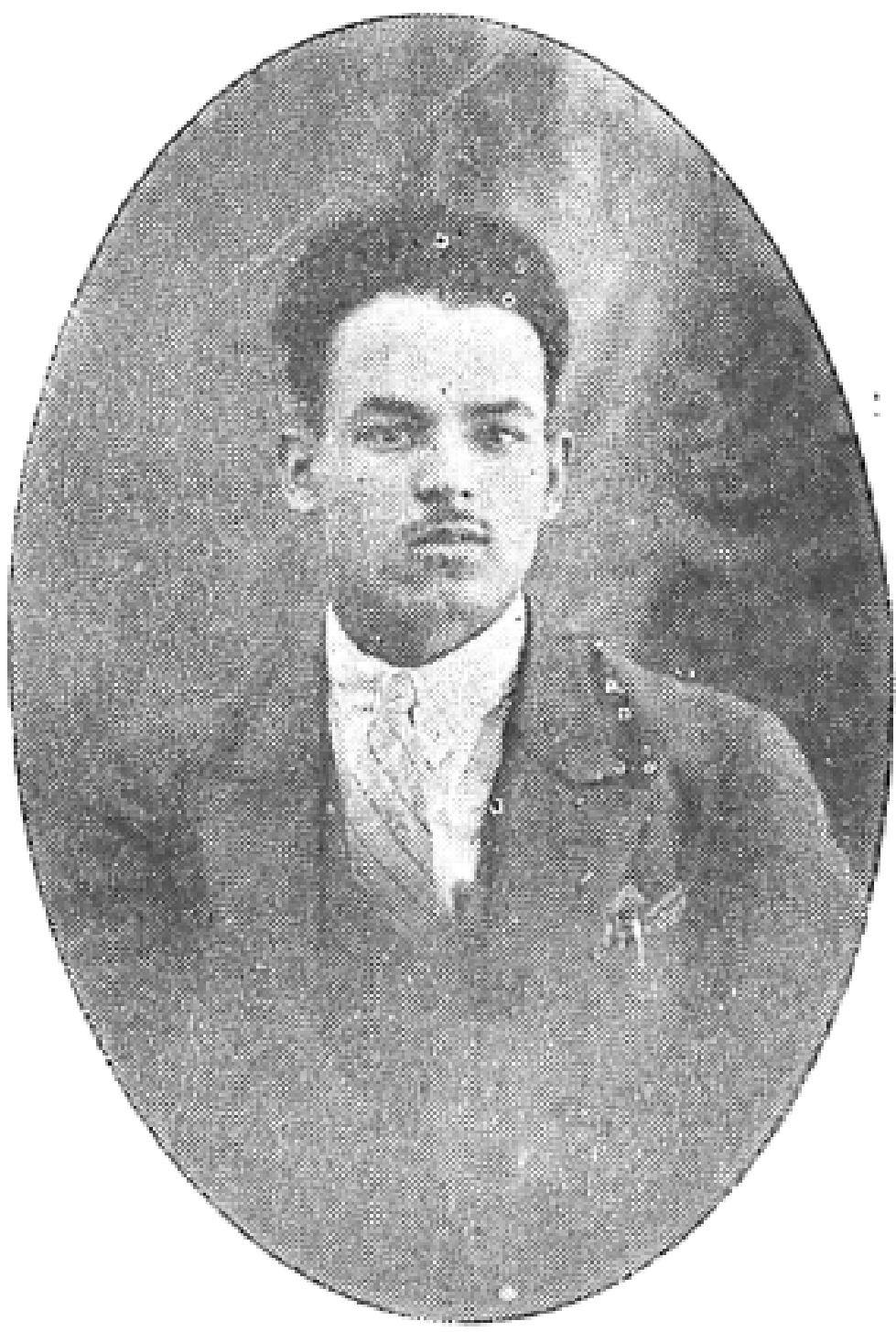

Al-Hādī al-Sanūsī, imagen reproducida en su antología, p. 4 


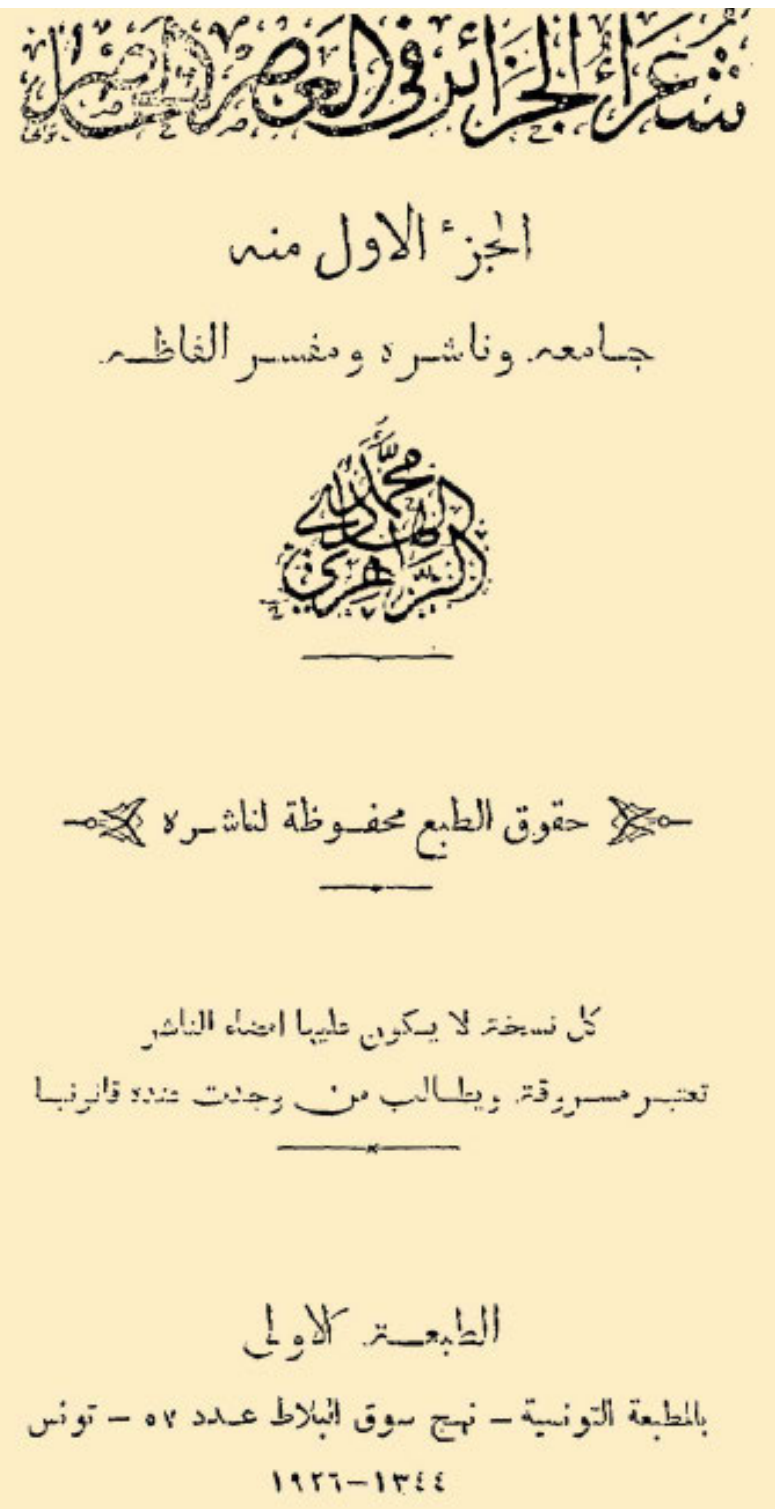

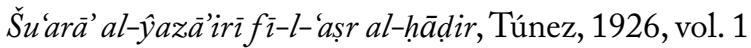




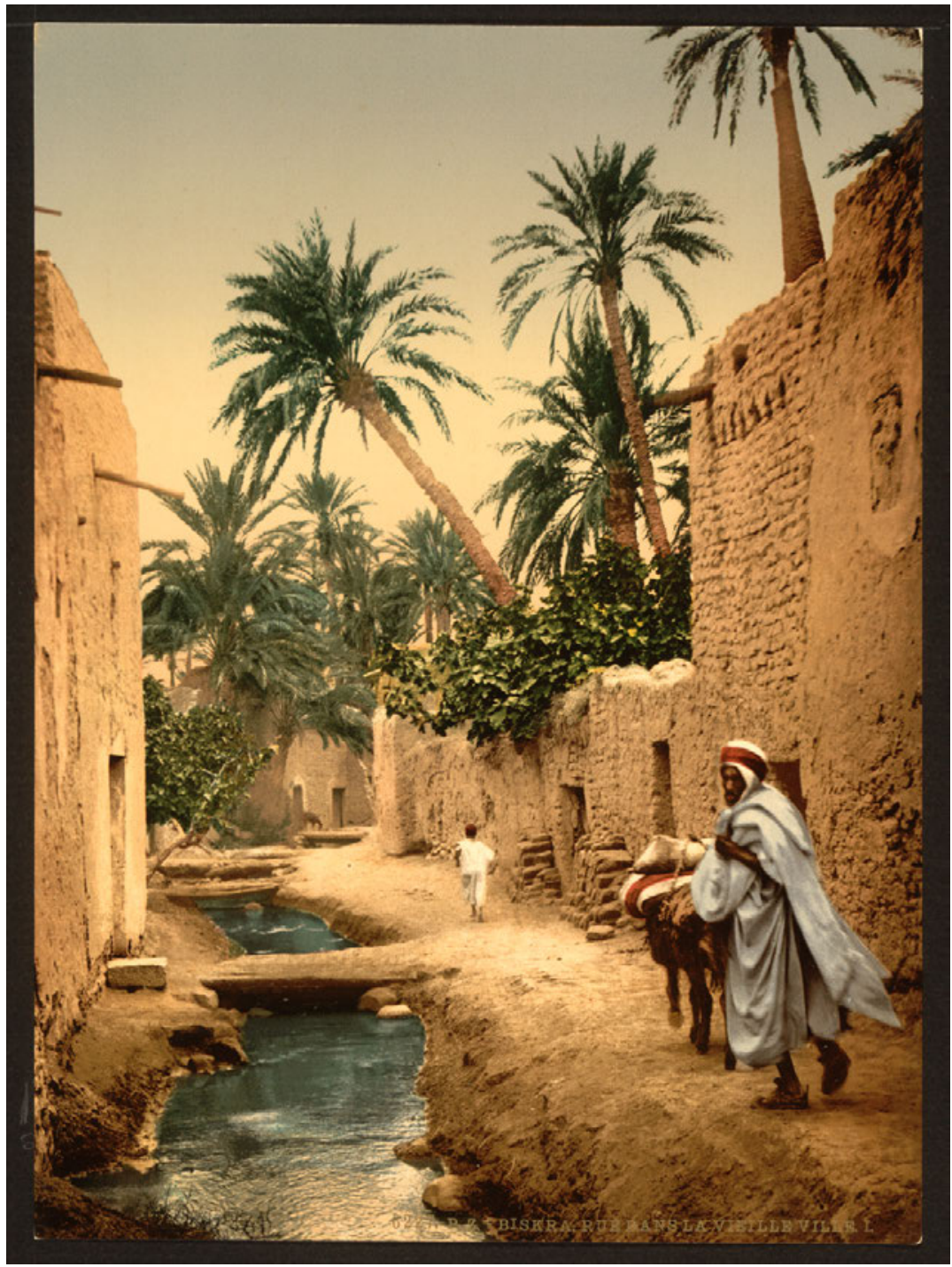

Impresión fotocroma de una calle en Biskra, Argelia, en «Imágenes de pobladores y sitios de Argelia»

del catálogo de la Detroit Publishing Company (1905), parte de la colección actual de la Biblioteca Digital Mundial 



\title{
SOBRE EL LENGUAJE EN \\ EL TEATRO ÁRABE ARGELINO (I)
}

\author{
NAIMA BENAICHA ZIANI \\ Universidad de Alicante
}

Mucho se ha hablado y debatido sobre la lengua usada en el teatro árabe ${ }^{1}$. De sobra es conocido que el teatro es una de las ramas artísticas que puede identificarse más íntimamente con el tiempo en el que se vive. Las obras teatrales responden al período en el que fueron creadas y permiten conocer a fondo los aspectos sociales, políticos, culturales y lingüísticos que rodeaban la vida de su autor. De ahí el hincapié en el lenguaje y su importante papel en el teatro.

Históricamente se sabe que el teatro árabe ${ }^{2}$ nació en el seno de los rituales religiosos, donde acumuló experiencia colectiva que refleja el efecto entre el actor y el público. Se emplea el lenguaje para transportar la idea del escritor al público, y no se diferencia de los gestos del actor para expresar y transmitir dicha idea. El lenguaje como fenómeno de voces y tonos es como un traje que complementa la personalidad y la decoración del escenario que describe el lugar.

El lenguaje es una herramienta de expresión, pero no solo, ¿cómo de fuerte es esta herramienta?, ¿'en qué consiste?, ¿de qué manera sale del artista para alcanzar al receptor? Y, ¿Son las reglas del lenguaje teatral adoptadas por él mismo, o cualquier lenguaje puede crear significado para alcanzar la meta deseada?

\footnotetext{
${ }^{1}$ Manuel Gómez García (ed.), Diccionario Akal de Teatro, Madrid, Akal, p. 807.

${ }^{2}$ Véase Mohammed Habib Samrakandi, Le théâtre arabe au miroir de luimême et son contact avec les créations des deux rives de la Méditerranée, Tolosa, Presses Univ. du Mirail, 2008.
} 
Si seguimos la evolución del teatro árabe, encontramos el problema de que el uso del lenguaje en su expresión teatral ha creado duros debates y posturas muy diferenciadas entre los críticos literarios. Para superar este problema hace falta una " $u-$ nión" que pueda ser comprendida por los árabes en general. El árabe clásico no se entiende en los círculos populares debido a la persistencia del analfabetismo pero sobre todo porque no se emplea en la vida diaria, sin embargo ha sido el lenguaje de la cultura, la literatura y la civilización.

$\mathrm{El}$ asunto del lenguaje teatral ha quedado como algo a lo que los autores y escritores han de enfrentarse. El escritor Anwār alMadawi ${ }^{3}$ habla sobre el funcionamiento del lenguaje de los cuentos y el teatro:

Estamos en el proceso de ver la composición de la narración en árabe clásico, para simplificarlo y que la expresión no resulte difícil para el hombre de a pie o para los que no han recibido una educación en árabe clásico; los diálogos entre personajes, ya sea en la obra escrita o en su representación, deben ser escritos en la misma lengua hablada por los personajes en la vida real, o en otras palabras, el lenguaje de la vida diaria. Para nosotros el horizonte es el doble objetivo de, por un lado, asegurar el mantenimiento del concepto técnico en el proceso imaginativo de las historias y, por el otro, el buen estado de la investigación sobre la respuesta del público respecto al contenido literario.

Años más tarde, y a este mismo proceso, se sumaron otros dramaturgos árabes. A modo de ejemplo, citaremos al omnipresente, gracias a sus valiosas contribuciones en colocar al teatro

${ }^{3}$ (Mahdia, 1920 - 1965) Escritor y crítico literario. Conocido más por su labor de crítico de la literatura árabe que como periodista o escritor que fue. 
donde se merece, Abdelkader Alloula ${ }^{4}$, autor de varias obras escritas en la lengua del pueblo.

Mientras tanto, otro grupo busca solucionar el problema reconciliando las dos posturas estableciendo un llamado "tercer lenguaje" oficial. Un experimento llevado a cabo por Tawfiq al$H_{\text {Hakimm}}{ }^{5}$, con su representación teatral El gaitero, en su propio ambiente egipcio - rural- empleando un árabe dialectal, y después con La canción de la muerte en árabe clásico, y tras la presentación de ambas obras llegó a la conclusión de que el uso del árabe clásico hace la obra adecuada a la lectura; pero su representación requiere su traducción al lenguaje que la gente habla. Al-Ḥakìm escribe en el epílogo de su obra El Acuerdo:

El uso del [árabe] clásico es aceptable en la lectura de la obra, pero si la representación requiere una traducción a la lengua que la gente pueda hablar, el [árabe] clásico no es el lenguaje definitivo para todas las situaciones.

El teatro no es un arte de lectura y audición solamente, es también el arte de lo "invisible", se dirige al mismo tiempo a todo un gran grupo de gente con diferentes gustos, culturas e ideas. Tiene que comunicarse con todos ellos y su deseo de admirar la belleza, el placer y la cultura. El arte del teatro debe ser un auténtico reflejo de la vida de las personas y los asuntos sociales, y que expuesto directamente a estos asuntos, alcanza la comprensión del sufrimiento humano universal.

${ }^{4}$ (Ghazaouet 1939 - Orán 1994). Se le reconocen varios trabajos en diversas disciplinas, todas ellas relacionadas con el arte, un arte que le convierte en uno de los mayores autores de su generación, en Argelia y todo el Magreb.

5 (Alejandría, 1902 - El Cairo, 1987) Escritor egipcio. Vivió en Europa hasta 1928. Ganó celebridad fuera de su país gracias a sus obras dramáticas La gente de la caverna (1933) y Edipo rey (1949), utilizando en ocasiones el dialecto local y con estilo sencillo. 



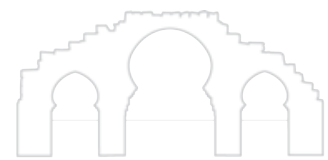

Reseñas y comentarios bibliográficos 



\section{ANTOLOGÍAS DE POESÍA ARGELINA CONTEMPORÁNEA EN LENGUA ÁRABE}

IsAac DONOSO

Universidad de Alicante

Emilio Sola y Mohamed Benmebrhout (coords.), País de larga pena... Pequeña antología de la poesía argelina contemporánea (1950

- 1978), Fuengirola, Cuadernos de la Afrobética, 1979, 176 pp. [ISBN: 84-300-1615-5]

SouHel Dib, Anthologie de la poésie populaire algérienne d'expression arabe, París, L'Harmattan, 1987, 160 pp. [ISBN: 2-85802-771-4]

Ahmed LANASRI, Anthologie de la poésie algérienne de langue arabe. Textes arabe et français, París, Publisud, 1994, 242 pp. [ISBN: 286600-439-6]

Jean DÉjeuX, La poésie algérienne. De 1830 à nos jours, París, Publisud, 1996, 109 pp. [ISBN: 2-86600-031-5]

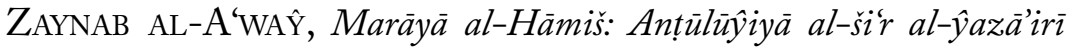
al-mu'āṣir, Argel, al-Faḍā’ al-Ḥurr, 2007, 252 pp. [ISBN: 9-96187431-8]

El papel que una reseña debe de cumplir es la de revisar la actualidad bibliográfica y valorar críticamente el papel de las nuevas publicaciones y su contribución al mejor conocimiento de un campo de estudios. Cuando ese campo de estudios no produce abundantes obras, y el seguimiento crítico es paupérrimo, se hace explicable la necesidad de revisar lo que se ha ido produciendo más allá del pasado inmediato. Y con la consigna de actualizar una serie de antologías poéticas que sobre la literatura argelina contemporánea han ido apareciendo, y vertebrarlas de algún modo para que reflejen una unidad de trabajos como 
fuente para el estudio de esta poesía, realizamos este breve comentario bibliográfico.

Éste es el contexto en el que se encuentra la poesía argelina y, en general, todo aquello relacionado con la literatura realizada en Argelia, país vecino geográfica e históricamente de España, pero del que culturalmente se conoce muy poco. $Y$ no es nuevo este desconocimiento, pues parece habitual que en los libros especializados sobre literatura árabe se afirme el escaso interés que ha despertado la literatura argelina, y lo muy poco que existe accesible al público español en monografías y traducciones ${ }^{1}$. Pero también es habitual igualmente valorar el potencial y las prometedoras perspectivas de futuro que la literatura argelina puede ofrecer al conjunto del mundo árabe:

La literatura argelina, como muchas de las facetas del propio país que las produce, aparece, cara al inmediato porvenir, como una de las más esperanzadoras y susceptibles de importantes hallazgos y realizaciones, dentro del ámbito general de la expresada en lengua árabe [...] En tal sentido, pues, $y$ en cuanto como tal literatura nacional acabe definitivamente de asentarse y hallar su línea propia y característica en el contexto general de la dramática y crítica existencia árabe contemporánea, representará sin duda una muy destacada voz a atender y armonizar, participando activa y decisoriamente en el concierto"2.

${ }^{1}$ Luis Miguel Pérez Cañada, "Panorámica de los estudios y traducciones de literatura argelina en español”, en Gonzalo Fernández Parrilla, Luis Miguel Pérez Cañada y Rosario Montoro Murillo (eds.), Panorámica de los estudios y traducciones de la literatura del Magreb en español, Toledo, Escuela de Traductores de Toledo, 1998, pp. 17-26; y después en "Literatura argelina traducida al español: panorámica", en Gonzalo Fernández Parrilla y Rosario Montoro Murillo (coords.), El Magreb y Europa: literatura y traducción, Cuenca, Universidad de Castilla La Mancha, 1999, pp. 339-352.

${ }^{2}$ Pedro Martínez Montávez, Introducción a la literatura árabe moderna, Granada, Universidad de Granada, 1994, pp. 186-187. 
Las palabras de Montávez, vistas con la perspectiva que da el tiempo, parecen describir agudamente la tendencia contemporánea del mundo árabe hacia la autodestrucción, o la incapacidad, por los motivos que quieran explicar politólogos y sociólogos, de crear sociedades estables en lo político y progresivas en lo económico. Sin duda por motivos de desestabilización e intervencionismo, también por la fragilidad de los estados postcoloniales, lo cierto es que la larga lucha por la independencia que varias generaciones de argelinos han tenido que librar, y el conflicto de identidad y diglosia lingüística que la agresiva política educativa francesa produjo, ha dado a la moderna Argelia un sustrato social e intelectual que favorece, y está favoreciendo, la agitación y la reflexión cultural. Y en efecto estamos asistiendo al encumbramiento de figuras argelinas en la primera línea literaria, tanto en la producción en francés, con Yasmina Khadra, como árabe, con Aḥlām Mustaganamī.

No obstante, lo cierto es que en el ámbito hispánico siguen siendo muy escasos lo trabajos que tienen la cultura argelina como objeto. Y la persona interesada en la literatura argelina cuenta con muy pocas referencias para acercarse a un mundo cultural que está, prácticamente, a la vuelta de la esquina, cruzando unas cuantas millas náuticas. Por todo ello, proponemos hacer en este comentario bibliográfico una pequeña relación sobre antologías de la poesía argelina contemporánea, con especial interés en la producción en lengua árabe, a pesar de que alguna pueda haber superado los años de rigor para formar parte de la actualidad bibliográfica.

Esto es lo que sucede con País de larga pena... Pequeña antología de la poesía argelina contemporánea (1950-1978), prácticamente la única antología disponible para el público hispanohablante sobre la poesía argelina. Lo cierto es que, salvo algunos 
poemas específicos ${ }^{3}$, no encontramos ninguna monografía en español que realice una antología poética argelina. De ahí la importancia de este texto publicado por la iniciativa de Francisco López Barrios y la coordinación de Emilio Sola, profesor español de larga estancia en Argelia. Lo cierto es que el volumen sólo recoge poesía argelina en francés, y anuncia que aparecerá otro segundo volumen con la poesía en árabe. Sin embargo ese segundo volumen prometido es ilocalizable, por lo que hay que suponer que nunca se publicó. Así que en español sólo contamos con este texto de obras en francés, reproducidas de forma paralela en original y traducción española en páginas consecutivas. Al menos se introduce el volumen con una sucinta introducción por Mohamed Benmebkhout, y algunos de los poemas son verdaderamente reveladores de la naturaleza poética argelina. En efecto, frente al conformismo y beneplácito al absorber la lengua del colonizador obedeciendo su discurso de progreso y superioridad cultural, los poetas argelinos denuncian la postración, ruina y letargo al que la educación en francés les condena:

Je n'ai pas de portée pour les notes qui naissent en moi on m’a donné des mots sans âme des mots aux yeux de chien battu.

No tengo un pentagrama

para las notas que nacen en mi. Se me han dado palabras sin alma palabras con ojos de perro apaleado ${ }^{4}$.

${ }^{3}$ Como los aparecidos en Leonor Martínez Martín, Antología de la poesía árabe contemporánea, Madrid, Austral, 1972, pp. 212-218, los que se anotan en Pérez Cañada, loc. cit., y quizá alguno que se nos haya pasado.

${ }^{4}$ Emilio Sola y Mohamed Benmebkhout (coords.), op. cit., p. 91. 
Este fragmento perteneciente al poema "Prefacio" de Boualem Khalfa muestra que los argelinos no asumen el francés de forma inconsciente y pasiva, sino que la intervención lingüística, la extirpación del propio patrimonio cognitivo y sustitución por otro impuesto, el lavado de cerebro, la visceralidad de la ingeniería cultural, y el cinismo de luchar contra el analfabetismo creando legiones de analfabetos en su propia lengua materna, no es un favor al cual van a dar las gracias. El poeta argelino, alienado, podrá escribir "palabras sin alma" en francés, pero mostrará igualmente su ira, la rabia de los ojos del perro apaleado. Lo mismo dirá Rachid Boudjedra: "¿Para qué sirven mis poemas, / si mi madre no sabe leer?". Y lo mismo dice Hamid Skif: "Nos engañaron / como se engaña a la bestia al acecho / como se engaña a niños tiernos / como se engaña a clientes tontos". Frente a otras literaturas mal llamadas "postcoloniales" - en otro juego cínico de la crítica literaria occidental, que quiere seguir perpetuando el hecho colonial y la centralidad del colonizador-, la literatura argelina no muestra pleitesía y avenencia con la lengua del colonizador, y denuncia, irasciblemente, la invalidez intelectual a la que le ha querido reducir el francés, a pesar de escribir en francés, precisamente por poder sólo escribir en francés.

El segundo texto explícitamente anuncia en su título que las obras antologadas tienen un original árabe. Sin embargo, y lamentablemente, todo el texto se reproduce en francés, sin añadir el original árabe en ningún lugar. Lo peor de todo ello es que no se trataba de textos en árabe clásico, sino precisamente en dialectal argelino, razón de más para obligadamente haber añadido las versiones originales. En efecto, Anthologie de la poésie populaire algérienne d'expression arabe de Souhel Dib, es un texto que deja al lector algo contrariado ya que, siendo una antología de poesía popular — en donde la lengua no tiene por qué reducirse a la norma culta, y el principal interés radica pre- 
cisamente en recoger esa muestra de lengua, como patrimonio intangible en peligro de desaparición-, no reproduce las fuentes. Y el objeto de esta antología no podría haber sido otro que el de reproducir las interesantes muestras de lengua árabe de los originales. En fin, esta ausencia no se explica convincentemente en la introducción, y lo que tenemos es una sucesión acrónima de poemas en francés organizados por temas: poesía religiosa, erótica, sátira y de combate, y elegíaca. Decimos acrónima porque tampoco se indican claramente los periodos que comprenden los poemas, seguidos uno tras otro en un todo, que va desde el siglo XVI al XX. Es decir, el lector no puede hacerse una idea del proceso estético o histórico en el que se desarrolla esta poesía, más allá de la descripción y adscripción a unos géneros poéticos tradicionales. Como colofón, de los autores antologados se reproduce al final del volumen unas pequeñas notas biográficas, sin indicarnos las fuentes de donde se extraen los datos.

El resultado de todo ello se asemeja bastante a las estrategias culturales de países colonizados a la hora de transvasar en la lengua del colonizador el patrimonio oral y popular (es decir, el que constituye la forja de un pueblo, según el ideario romántico-nacionalista) de la lengua que se quiere culturalmente sustituir. No obstante, la obra sí que ofrece elementos interesantes, y las notas que apuntamos quieren abundar en que, más favor se le hubiera hecho al objeto de estudio —en este caso la poesía popular argelina en lengua árabe-, reproduciendo los originales y analizando directamente su naturaleza, más que reproduciendo una sucesión de poemas en francés descontextualizados. Pero sin duda sí es relevante lo que menciona Souhel Dib en su introducción, en torno al origen de esta poesía argelina, y la relevancia del elemento andalusí:

La poésie d'origine andalouse va s'enrichir de nuances nouvelles, traduisant le tempérament d'un type d'homme issu 
des syncrétismes andalous et autochtones [...] Dans un premier moment, la floraison de la poésie érotique est due au lyrisme directement hérité des cours de Grenade, de Séville et de Cordoue ${ }^{5}$.

Quizá de nuevo hubiera faltado abundar con más documentación que pudiera reflejar esa supuesta y determinante influencia andalusí. En cualquier caso, dada la escasez bibliográfica sobre el tema, la obra de Dib al menos es un primer elemento del que se pueden extraer datos para seguir reconstruyendo el objeto de estudio.

El tercer volumen antológico que vamos a comentar por fin nos ofrece textos en original árabe más traducción francesa, reproducidas primero las traducciones, después los originales: Anthologie de la poésie algérienne de langue arabe. Textes arabe et français, obra de Ahmed Lanasri. Aunque el título no lo expresa explícitamente, toda la poesía recogida pertenece al periodo moderno y contemporáneo, y no a textos de la poesía árabe histórica realizada en suelo argelino. La obra divide en tres etapas la poesía contemporánea: Renacimiento, Renovación y Liberación. Aunque no se define en los enunciados una clara separación cronológica, el periodo de Renacimiento comprendería la Nahda árabe hasta el comienzo de los años 20, la etapa de Renovación sería el periodo de entreguerras y el preludio de la revolución argelina, y la etapa de Liberación las últimas fases de la guerra de liberación, la independencia en 1962 y las primeras décadas del nuevo Estado argelino.

Tras una breve pero completa introducción de los tres periodos, se reproducen los poemas en traducción francesa divididos también en tres secciones, seguidos de las versiones originales en árabe, igualmente divididas en tres secciones ( $\check{S}_{i}$ r al-nahḍ, Šir al-Tâydìd, Šír al-Taḥrīr), con anotación de la fuente de la

${ }^{5}$ Souhel Dib, op. cit., p. 10. 
cual se extrae el texto árabe. En la sección francesa, cada autor es introducido por una glosa biográfica y, en general, de cada autor se reproducen dos o tres poemas. Se trata por lo tanto de un libro muy valioso, ya que anota las fuentes de los originales árabes y los reproduce, con la importancia que ello tiene para la poesía árabe moderna, ya que permite visualizar rápidamente el proceso de descomposición de la casida clásica. En fin, la obra de Lanasri es una antología esencial dentro de la escasa bibliografía sobre la poesía argelina en árabe.

También divide en tres periodos la poesía argelina la siguiente obra que reseñamos (1830-1920; 1920-1945; después de 1945), que no es tanto una antología como una panorámica crítica de la historia de la poesía argelina contemporánea, sobre todo francesa, pero también árabe: La poésie algérienne. De 1830 à nos jours. $\mathrm{Y}$ ahí tal vez radica la importancia de reseñar este libro, obra de Jean Déjeux, uno de los principales críticos de la literatura magrebí de expresión francesa y de los defensores de su valoración nacional. En efecto, a pesar de no ser una antología, creemos que es necesario resaltar esta obra como prueba de la transformación que la crítica francesa ha ido experimentando, abandonando los apriorismos del estudio del hecho literario en términos postcoloniales. La literatura puede ser un hecho político, pero es sin duda un hecho artístico. Reducir el estudio literario de la creación en una lengua impuesta al colonizado, desde el punto de vista del colonizador, desde su ámbito cultural, comodidad institucional y difusión editorial, es seguir perpetuando la herida del proceso de desarraigo cultural fruto del intervencionismo colonial. En otras palabras, no sólo es necesario, sino conditio sine qua non, que el estudio de las literaturas surgidas en la lengua del colonizador se estudien desde la perspectiva de aquel que asume una nueva lengua para crear una nueva realidad. Hay que ir más allá del plano colonizador-colonizado, para asumir una ecuación hegeliana en la que ambos 
términos crean algo nuevo, algo válido para la nueva realidad creada. La Argelia de 1830 no es la misma Argelia de 1962, y es además imposible volver a un momento previo. El estudio del hecho literario debe asumir por lo tanto el análisis de los procesos culturales per se, sin falacias, ideologías o esencialismos que coarten su naturaleza sintética.

Creemos que Jean Déjeux se ha ido acercando a estos planteamientos, y de algún modo asume el proceso de adopción del francés como lengua empleada para producir literatura por una parte de la población argelina, y estudia al mismo tiempo el desarrollo de la creación en árabe dentro de este contexto de transformación cultural. Así, concluye su estudio haciendo frente a la gran cuestión: "Le problème de l'expression française", la cual resuelve haciendo hablar a los propios argelinos, que sean ellos los que den respuesta a por qué emplean el francés. $Y$ añade un elemento con el que busca ejemplificar ese proceso de síntesis, el del uso de la poesía por parte de una comunidad árabe como voz de la comunidad, como voz de la tribu frente al enemigo, aunque sea en la lengua del propio enemigo:

Dès 1830 , nous voyons le poète au premier rang pour exprimer les sentiments profonds de ses compatriotas, au rythme des événements et au niveua des tribus dispersées ou même de toute l'Algérie investie. Le poète contemporain d'expression française assume le même rôle. Mais il n'oublie pas qu'il sait aussi chanter d'autres thèmes que ceux de l'homme-révolté6.

No obstante, como podemos leer, Déjeux va más allá de reducir el hecho poético a la voz del pueblo. La poesía no puede ser un mero vocero político, sino que sobre todo es voz de la expresión individual. De ahí que el problema de la poesía argelina

${ }^{6}$ Jean Déjeux, op. cit., p. 91. 
en francés, más allá de la independencia política, deba enfrentarse a la identidad individual.

Finalmente vamos a hablar de la obra más reciente en el tiempo y que alcanza de algún modo los parámetros que el objeto de estudio estaba demandando: poder tener una obra referencial con las principales composiciones poéticas contemporáneas argelinas en lengua árabe. Se trata del libro de Zaynab al-

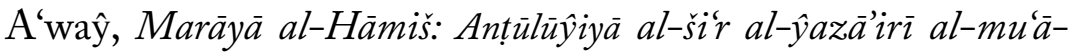
sir / مرايا الهامش: انطولوجيا الشعر الجزائرى المعاصر : "Espejos al margen: Antología de la poesía argelina contemporánea". Su autora es poeta argelina y profesora en el departamento de árabe de la Universidad París 8. El libro responde a las líneas de la antología de la novela árabe argelina publicada en la misma casa editorial por Wāsīnī al-A'raŷ, y de la que hablaremos en otro trabajo. Se trata de hacer accesibles al gran público las grandes obras de la literatura argelina en lengua árabe. Se trata por lo tanto de crear un canon literario sobre la clasicidad de una literatura, sin duda ya nacionalizada tras varias décadas de independencia y de oficialidad de la lengua árabe, y de una literatura que se constituye ya no como una promesa, sino como una auténtica realidad dentro del mundo árabe. A partir de aquí, ya depende de nosotros querer saber más o menos sobre la capacidad creativa de nuestros vecinos del sur, herederos del legado andalusí, y uno de los principales motores actuales de la modernidad árabe. 


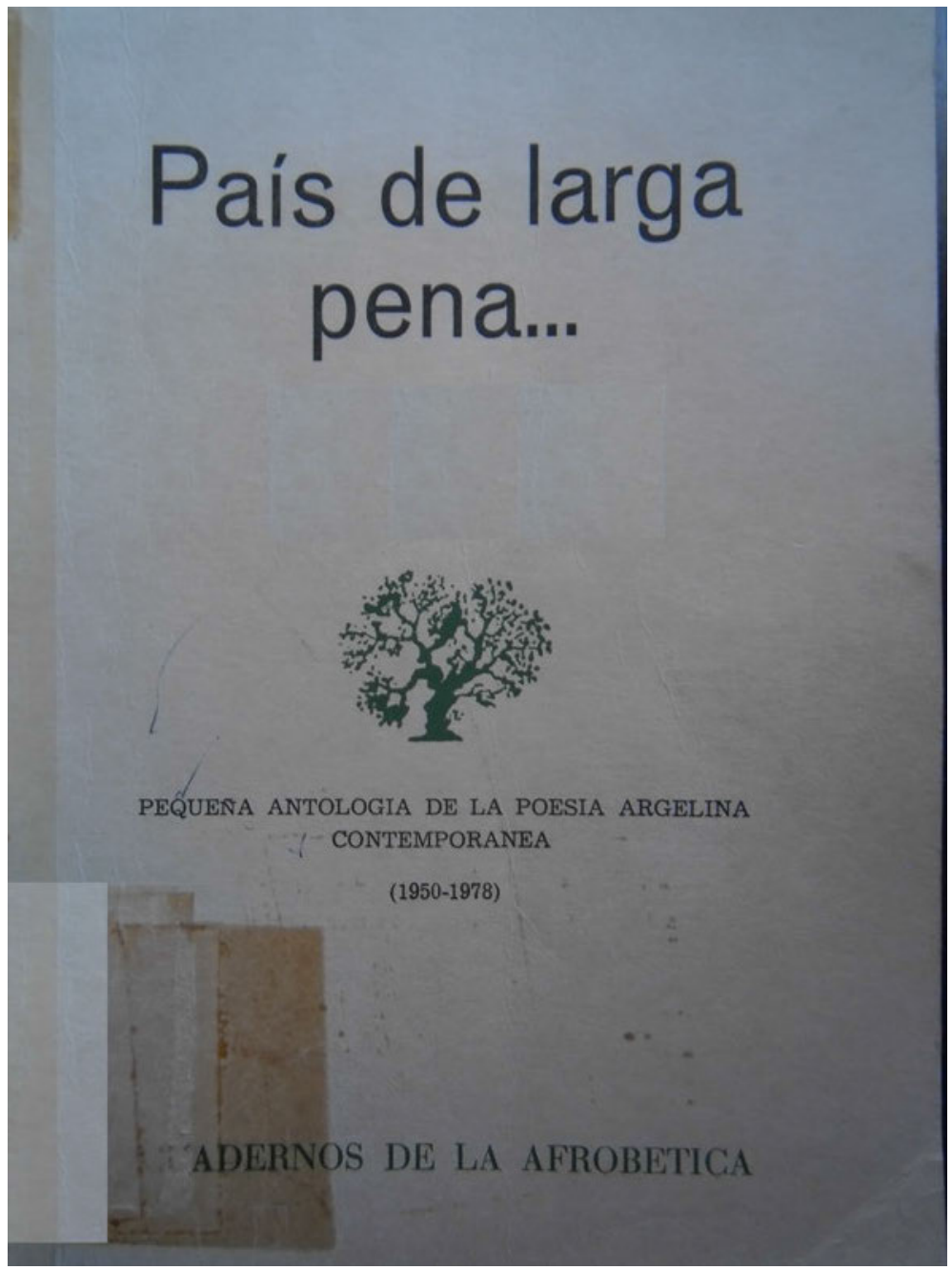



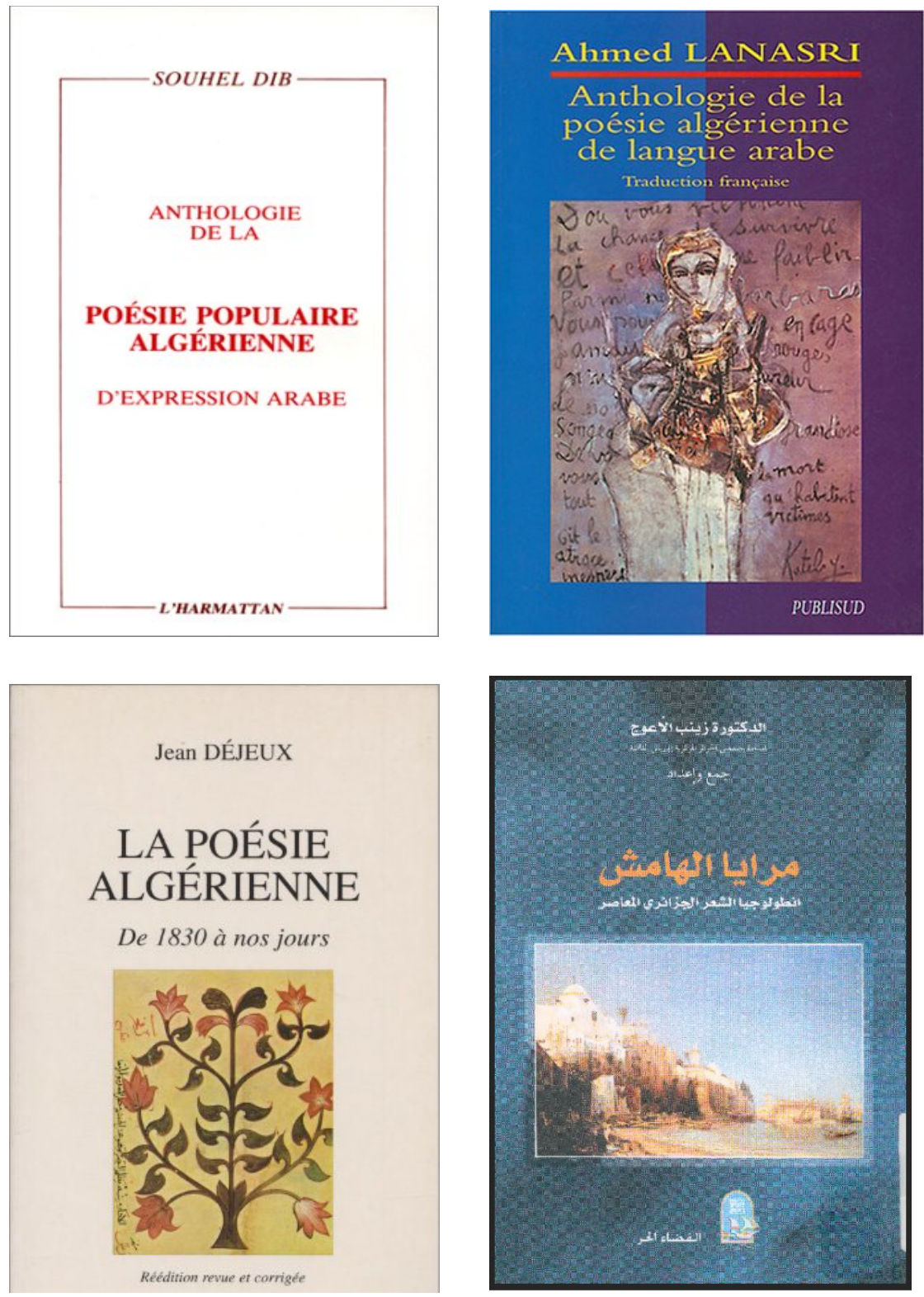


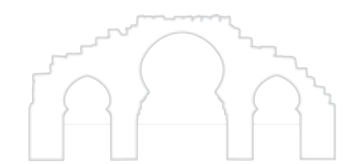

Biblioteca 



\section{L'ENFANT-JAZZ DE MOHAMMED DIB \\ NAIMA BENAICHA ZIANI \\ Universidad de Alicante}

\section{NOTA BIOGRÁFICA}

Mohammed Dib (1920-2003) es uno de los escritores más representativos de Argelia y de la literatura contemporánea. Está considerado como uno de los mayores y más galardonados poetas argelinos de la historia, así como un puente de unión entre la literatura francesa y la argelina junto a su contemporáneo Albert Camus.

Poeta, novelista, ensayista, autor de cuentos y obras de teatro, nació en Tlemcen (Argelia) pero pasó gran parte de su vida en Francia, tras ser expulsado en el año 1959. Su considerable obra (más de treinta textos impresos) ha recibido varios premios, entre los cuales destacan el «Gran Premio de la Francofonía» de la Academia Francesa en 1994 (otorgado por primera vez a un escritor del norte de África), y el premio «Mallarmé» por su colección de poemas El niño-jazz (1998). Murió el día 3 de mayo de 2003 en Saint-Cloud, Francia, su residencia, donde pasó sus últimos años de vida.

\section{L'ENFANT-JAZZ}

La idea central del poemario es la visión inocente del niño con el mundo que le rodea; el autor trata de profundizar éste concepto a través de los ojos de un niño abandonado, libre, no corrompido y puro. El poeta intenta reflejar y transmitir las emociones que despierta el mundo en el niño, al igual que en el 
mundo de la música, el jazz busca esta transmisión de emociones.

Las tres partes del libro (Aquí, Otro lugar, y La guerra) corresponden a las tres partes de la estructura (inicio, nudo y desenlace). El narrador habla a través de los ojos de un niño abandonado y desorientado que intenta aprender la esencia de la vida mediante varias e insistentes preguntas sin respuesta. El niño intenta descubrir el secreto de la felicidad, de la libertad, del abandono o del miedo en la luna que no encaja en la oscuridad, el dios loco, o en la mariposa "con sus colores vivos".

El personaje central de la obra es un niño cuyo nombre no se especifica, pero que podría ser identificado con el propio autor, un chico que pasó su infancia en plena guerra, huérfano desde los once años. Lo que sabemos a menudo sobre el personaje es lo que ve y cómo percibe cada cosa, cada detalle. Esto hace que el autor pueda describir algo tan simple como el acto de fregar o simplemente un instante con una belleza y profundidad asombrosa. El niño-jazz comienza por ser un buen observador cuando no hay nadie a su lado y empieza a ver todo lo que le rodea. Sus preguntas son infantiles y casi obsesivas, y todo lo que observa se lo repite al oído para intentar memorizarlo. Luego, hay un momento de tránsito en el poema "La risa", cuando el niño dice: "Si se supiera todo, ¿que quedaría por saber?”. Con esta pregunta retórica el protagonista da un paso adelante en su evolución como persona. Al final de la obra, el niño parece que se desencadena, aunque nadie lo escucha y se tiene que dirigir a un muro.

La naturaleza en general está personificada por el niño cuando intenta buscar la esencia de la vida y el significado de sus sentimientos en las cosas que le rodean. Cada objeto tiene una característica, pero son más símbolos que personajes.

Hay varios ejemplos en este sentido, como la sombra, la noche, el espejo, el corazón olvidado que simboliza el propio a- 
bandono que siente el niño, el perro pasando por la calle que es el paso del tiempo, la mariposa como la libertad y la esperanza, o la luna que no encaja como la angustia del niño. La madre tendría que ser el personaje secundario más representativo, el apoyo principal del niño, o por lo menos un escudo para su hijo, símbolo de la protección. Pero no, lo que el lector encuentra mediante la vista del niño es una madre muy estática, casi petrificada, callada. El papel de la madre en el libro es el de fortalecer la imagen del protagonista, porque un niño sin madre deja de ser niño.

Los poemas de ésta colección son muy simples. Dib utiliza el lenguaje de la inocencia para representar el mundo de la experiencia. Es decir, el lenguaje es el de un niño cualquiera, sencillo y rudimentario, que a veces da la impresión de ser incluso negligente ("Él se miraba en él", El espejo - repetición; La calle vacía. El perro - no hay verbo; etc.). Pero el poder y el afinamiento del libro están en la misma sencillez y aparente negligencia, en la capacidad del autor de dar musicalidad a los poemas y expresar sentimientos con palabras básicas. Como el propio autor dice, "el ejercicio de la poesía exige tal afinamiento, una búsqueda tan intensa de la expresión, una concentración tal en la imagen o en la palabra, que terminamos en un callejón sin salida”.

Además de utilizar palabras simples y puras, igual que los sentimientos de un niño, el autor innova en la estructura y la puntuación; utiliza poemas sueltos y frases muy cortas. Se puede observar como casi cada línea lleva un punto al final ("Bajó los ojos. / Un arroyo fluía.", Paisaje) o incluso frases de dos o tres palabras ("Si, dijo el niño. Sí, dijo él / No, dijo el niño. No. dijo él / Sí, dijo el niño. Sí, dijo él.", Los aromas; "Sin hablar. Esperando. Sentada.", El río).

Respecto a la puntuación, otro aspecto importante es la multitud de preguntas del niño, normales para cualquiera, pero al 
mismo tiempo incomodas, y muchas veces sin respuesta (" $¿ Q u e ́$ escondía el espejo / además de su rostro?”, El espejo; “¿Y este corazón olvidado? ¿A quién? / ¿A quién pertenece?”, Una cosa; etc.). Son preguntas que implican silencio por parte del lector que no sabe responder, y como Dib afirma, "la poesía, como la música, está rodeada del mayor silencio".

La técnica de escritura que ha empleado el autor es la narración con descripciones y diálogo / monólogo. Es narración porque hay alguien que cuenta todo lo que hace el niño; es un narrador omnisciente porque además de observar todos los acontecimientos, sabe y relata los sentimientos e intenciones del protagonista ("Se sintió observado.", "Hubiera querido gritar." La guerra, XX; "El niño podía creer / Que siempre seguía allí." - El perro). Es un narrador peculiar, porque narra con la vista del mismo protagonista.

También hay descripciones cuando el narrador detalla lugares o escenas ("En ese preciso instante $[\ldots]$ / Cuando las personas abren / Los ojos y se quedan dormidas." - E1 momento). Diálogo no hay, pero monólogo sí, por la presencia de las frecuentes preguntas del niño anteriormente mencionadas. Es una interacción muy activa con el lector.

A primera vista, el título no corresponde al contenido porque hoy en día la palabra jazz tiene otro significado al que tenía hace medio siglo. Cuando pienso ahora en jazz, lo que veo es un saxófono, un piano, quizá gente sentada en las mesas y disfrutando de la música, y afroamericanos cantando (no esclavos). Para entender el título hay que relacionar la biografía del autor con la etimología de la palabra jazz; hay que saber que Mohammed Dib trabajó en la Universidad de California en los años 70, y que tenía una debilidad por los afroamericanos, y especialmente por el jazz y el blues. En el prefacio el autor afirma que para él, el jazz es el niño que hay dentro de cada uno de nosotros, igual que la creatividad. 
La descripción es la parte más impactante porque da la oportunidad (al lector) de meterse en la piel de un niño. La infancia es algo que siempre despierta nostalgia en cada uno de nosotros, un periodo de nuestras vidas al que nos gustaría volver pero no podemos. El autor crea la vista pura e inocente de un niño con unas descripciones simples y sin abundancia de figuras retóricas.

No es un libro para los aficionados del jazz; es un libro para los aficionados a la libertad, a la esperanza, y para los que quieren leer el drama de un niño abandonado que, en plena guerra, busca la esencia de la vida. Es un libro para los que quieren ver a un niño que, sin culpa alguna, va desorientado en búsqueda de un trayecto que nadie le ha trazado.

\section{SELECCIÓN}

La risa

Estos murmullos perdidos.

Esta luz, este oro.

Que colmaba el viento.

El niño dijo: quizá

Saldrá un monstruo

Pero ¿̈por qué decirlo?

Un monstruo muy hermoso.

Quizá seamos felices.

Tan hermoso, dijo.

Hubo entonces una risa.

Tan hermosa y una sola vez

$Y$ no se repitió más. 
Si se supiera todo, dijo

¿Qué quedaría por saber?

Oyó sollozar.

La mariposa

Quizá ciega.

Quizá sorda y ciega.

Sólo ella libre

En la luz del crepúsculo

Una mariposa aún danzaba.

Mudos los árboles, mudo el cielo.

Mudos los matorrales, mudos los prados.

Sólo sus colores vivos.

Y la cosa venía, ciega

Muda y quizá sorda.

\section{El momento}

En ese preciso instante

$Y$ en el instante siguiente

Sin guerra ni muertos.

Cuando las personas abren

Los ojos y se quedan dormidas.

O cuando las flores brotan.

Por más que se les demuestre amor,

O uno se acerque, o se aleje.

No cambian su expresión. 
El perro

La calle vacia.

Luego pasó un perro.

Luego otra vez vacía.

Pronto la noche cayó.

Cayó despacio.

¿Qué vendría ahora?

No fue un perro

Lo que pasó. Sino el tiempo.

Asípasaron mil años

El niño podía creer

Que siempre seguia alli.

\section{La Guerra}

XX

Hizo un gesto

Se sintió observado

Tan sólo que la guerra

Arrastraba mucha belleza

Se podía morir por ella.

Yo no, decía él.

Hubiera querido gritar.

La guerra avanzaba iluminando

La calle con su rostro. 
Yo no, decía él.

Yo no. Este vacio oscuro

Que no acaba.

La oscuridad es mi amiga.

Y la luz de la guerra

Que inunda la calle.

Llego ante un muro

Y grito. Grito oscuridad.
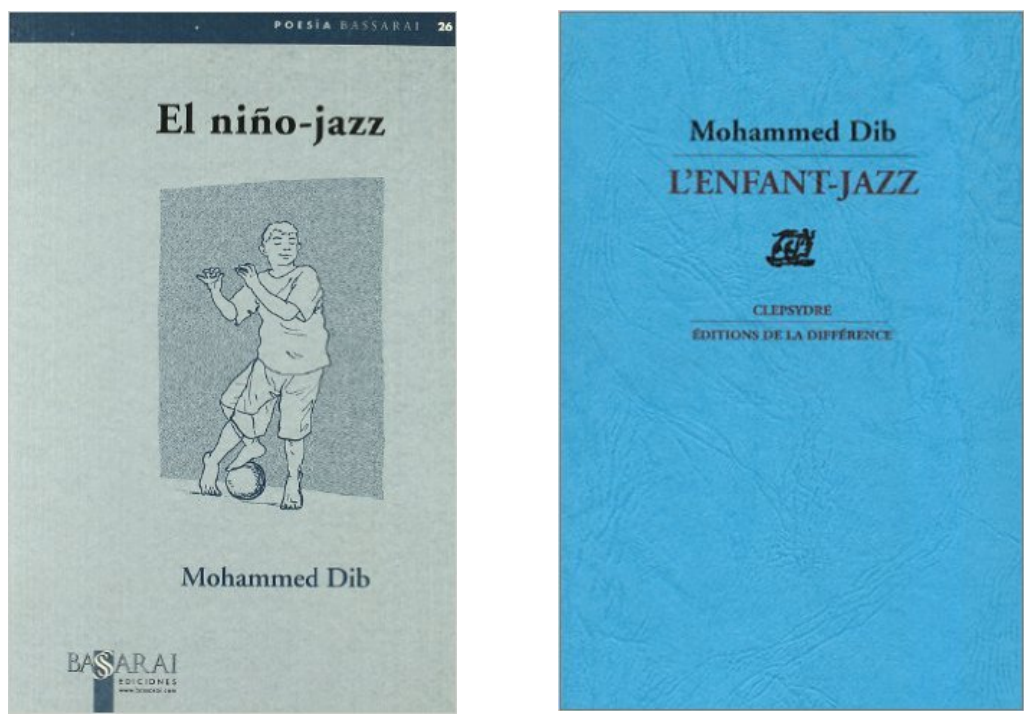


\section{Criterios de edición:}

Revista Argelina. Revista semestral de Estudios Argelinos es una publicación electrónica e impresa evaluada por pares con tres criterios de selección: 1) aceptación; 2) aceptación con cambios; 3) devolución. Se aceptan contribuciones en castellano, valenciano, árabe, francés e inglés.

Los originales se presentarán registrándose como usuario y subiendo el documento a la plataforma OJS de la página electrónica: $\underline{\text { http://argelina.ua.es }}$

El aparato crítico deberá ajustarse a las siguientes normas de edición:

-Texto en formato estándar a un espacio de interlineado.

-Fuente en Romanas (Times New Roman) a 12 puntos.

-Título del trabajo en mayúsculas a 16 puntos seguido en línea inferior por el nombre del autor en versalitas.

-Notas a pie de página a 10 puntos.

-Cita: Libro (Nombre, Titulo, Ciudad, Editorial, Año); Artículo (Nombre, "Título", en Revista, Año, vol. X, núm. X, pp. $\mathrm{XX})$.

-Sistema internacional para las citas y transcripciones del árabe. 


\section{معايير النشر :}

المجلة الجزائرية هي مجلّة علمية ومحكمة، مخصصة للدراسات المتعلقة بالجزائر، مقرّها بإِسبانيا، تطبع

$$
\text { أعدادها ورقيا وإلكترونيا كل ستة أشهر. }
$$

يستقبل المركز طلبات نشر الأبحاث والدراسات المنجزة وفق معايير الكتابة والنشر الخدّدة في متن هذه

- تخضع المواد المرسلة كلّها للتّقييم والقراءة الأكاديميّة.

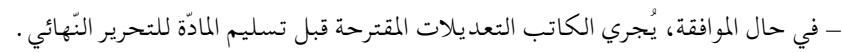

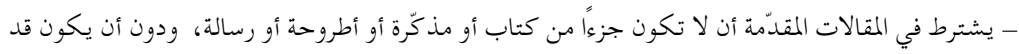
تمّ تقديمها سابقا لأي جهة علمية أخرى.

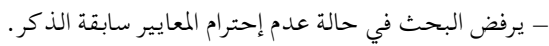

$$
\text { يمكن المساهمة باللغات التالية : العربيّة، الإسبانية، الفرنسية، الفلنسيانية والإنجليزيّة. }
$$

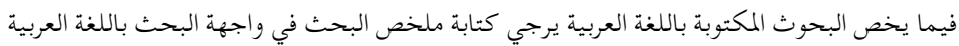

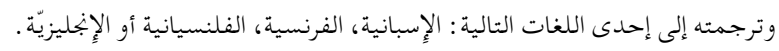

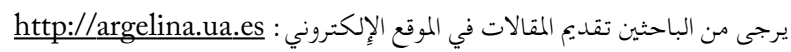

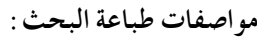

بهدف توحيد توثيق المصادر بشكل علميّ في كلّ أبحاث البجلة، يُرجى من الباحثين الكرام اعتماد أسلوب

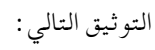

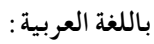

Traditional Arabic خط العناوين :بنط 16 ثقيل - خط المتن: بنط 16 عادي Traditional Arabic - خط الهوامش: حجم 12 عادي Traditional Arabic

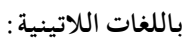
- تنسيق النص القياسي في مسافة سطر.

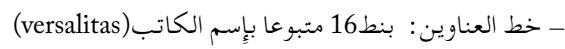
- خط المتن: بنط12 عادي(Times New Roman)

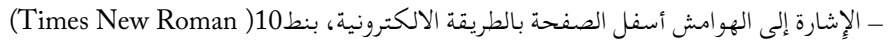

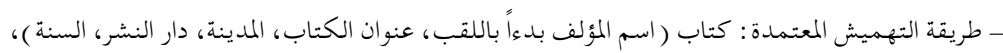

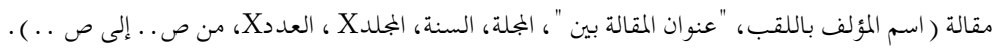

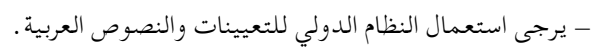

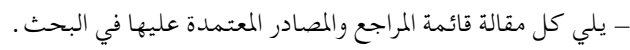




$$
\text { العددالثالث ـ خريف } 2016
$$

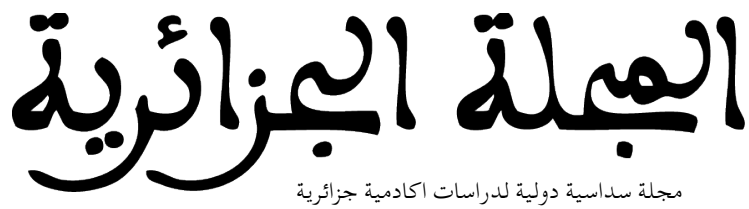




\section{الحمبلة إحيحزائرِية}

\section{ÍNDICE}

\section{Presentación}

La Universidad de Alicante y los «Estudios Argelinos»:

una publicación necesaria

\section{Artículos y notas}

IsaAc Donoso

Al-Hādì al-Sanūsì y la concepción de la cultura argelina .................... 11

Naima Benaicha Ziani

Sobre el lenguaje en el teatro árabe argelino (I) ............................... 23

\section{Reseñas y comentarios bibliográficos}

IsaAc Donoso

Antologías de poesía argelina contemporánea en lengua árabe

\section{Biblioteca}

Naima Benaicha Ziani

Lenfant-jazz de Mohammed Dib

43 